\title{
INFLUENCE OF POLLUTION BUILD-UP AND PAVEMENT CROSS-SECTION ON PERMEABLE PAVEMENTS UNDER EXTREME RAINFALL EVENTS
}

\author{
MIRIAM FERNÁNDEZ-GONZALVO, CARMEN HERNÁNDEZ-CRESPO, \\ MIGUEL MARTÍN \& IGNACIO ANDRÉS-DOMENECH \\ Instituto Universitario de Investigación de Ingeniería del Agua y del Medio Ambiente, \\ Universitat Politècnica de València, Spain
}

\begin{abstract}
Permeable pavement systems (PPS) are part of the stormwater management technologies known as Sustainable Urban Drainage Systems (SUDS). The main objective of this is to analyse its buffering capacity (quantity and quality of filtered water) under extreme rainfall events. To this end, two different pavement cross-sections, complete configuration (C1) and simple configuration (C2), have been tested at laboratory scale for the 25-year return period 10-min intensity rainfall in Valencia (Spain). Four different pollutant build-up levels have been studied (at one, three, six and 12 months). For all the simulated rainfall events, the quantity (hydrographs and drained volume) and quality (DQO, TSS, TN and TP concentrations) of filtered water were characterized. On the one hand, configuration C1 reduced more than $\mathrm{C} 2$ the peak flow of filtered water for the same dirt and dust build-up. Moreover, peaks are wider in time, so the filtered water is better distributed. Regarding the influence of pollution build-up level, it can be observed that higher dust and dirt build-up gave rise to lower flow rates. In general, the larger the quantity of pollutant build-up accumulated on the pavement surface, the larger the volume of water was retained because it absorbed part of the rain, thus smoothing the peak flow of filtered water. On the other hand, the pollutant mass leached from the pavement $\mathrm{C} 1$ is lower than $\mathrm{C} 2$. When the amount of dust and dirt deposited was lower, the rainfall was able to leach more pollutant with respect to the total mass deposited. The results show the importance of an adequate cleaning program with a frequency no lower than once a month and a better response, in terms of water pollution retention, of the complete configuration $(\mathrm{C} 1)$ during times of heavy rainfall.
\end{abstract}

Keywords: porous pavement, extreme rainfall intensity, pollutant build-up, infiltrated water quality, laboratory experience.

\section{INTRODUCTION}

Since the beginning of urban development, the water cycle had been altered. When it rains on a natural landscape, water infiltrates into the soil, evaporates, is taken by plants (evapotranspiration) and sometimes finds a way into rivers. But when it rains in an urban area, in which permeable surfaces are so scarce, a great part of rainwater turns into surface water runoff, which can cause flooding, pollution and erosion problems. Sustainable Urban Drainage Systems (SUDS) are an opportunity to prevent urban soil sealing. They can take many forms, but the main idea is to manage and use rainwater close to where it falls, i.e. at source. Therefore, the pillars of SUDS design are four: control the quantity of runoff, manage the quality of runoff to prevent pollution, create and sustain better places for people and create and sustain better places for nature [1].

Permeable Pavement Systems (PPS) are one specific type of SUDS. A large number of studies have shown the hydraulic benefits of these systems, including: reduction of surface urban runoff and peak flow attenuation, reduction of combined sewer overflows, groundwater recharge [2] and mitigation of urban heat island effect [3]. Nevertheless, there are few research about the second pillar of SUDS design (water quality), although the number has been growing in recent years [4]-[6]. 
Studying the response of SUDS to high rainfall intensity events is important to demonstrate their ability to face future challenges associated with climate change, as the Intergovernmental Panel on Climate Change expects that the extreme precipitation events will become more intense and frequent [7]. It has been claimed and demonstrated that incorporating SUDS into urban planning development becomes necessary [8], and other authors also consider that urban green assemblages (equivalent definition for SUDS) has the potential to create more resilient cities with the capacity to respond to a broader scope of climate change and environmental issues [9].

The main objective of this research is to analyse the buffering capacity of permeable pavements, in terms of quantity and quality of filtered water under extreme rainfall events. The aim will be achieved quantifying the hydraulic and pollutant retention capacity of the PPS performed in laboratory under different dust and dirt build-up levels. Moreover, another goal of the study is to define the minimum cleaning frequency for PPS according to their configuration.

\section{MATERIALS AND METHODS}

\subsection{Materials}

The experimental setup designed to achieve the objectives of the study consists of a battery of laboratory scale infiltrometers, as shown in Fig. 1(a). Two configurations of pavement layers were tested: full configuration $(\mathrm{C} 1)$ and simple configuration $(\mathrm{C} 2)$. Both sections are also illustrated in Fig. 1(b). Configuration $\mathrm{C} 2$ has the same layers as $\mathrm{C} 1$ except the bottom layer of washed limestone aggregate $4-40 \mathrm{~mm}$ size. Both configurations were tested to understand the role of the gravel layer. When the traffic load is not high (e.g. on sidewalks) the bottom gravel layer is dispensable, because less structural strength is required. The concrete block characteristics, according to the information provided by the manufacturer, can be found in Hernández-Crespo et al. [10].

The rainfall simulator is based on [11] and is composed of a water storage tank, a pump and a grid of a drip irrigation pipes consisting of 7 rows with 13 drippers per row evenly distributed and placed $50 \mathrm{~cm}$ above the pavement surface (see Fig. 1(a)). A rain gauge is positioned below each permeable pavement to measure the infiltrated water flow, which is then collected and kept in a refrigerator until chemical analysis is performed, in less than 24 hours.

Deionized water was used (Electrical Conductivity: $10 \mu \mathrm{S} / \mathrm{cm}, \mathrm{pH}: 7.1$ ) to simulate rainwater. The material used to simulate pollution build-up is real dust and dirt deposited on urban roads. It was collected by the road cleaning services of the university (Universitat Politècnica de València - UPV), by a mechanical sweeper in dry conditions. The characteristics of this dust are collected in Table 1 and more detailed information is available in Hernández-Crespo et al. [10].

\subsection{Methods}

Rainfall simulations which reproduce the event with a return period of once in 25 years in Valencia (Spain) were performed. In particular, this rainfall intensity corresponded with $22 \mathrm{~mm}$ in $10 \mathrm{~min}(132 \mathrm{~mm} / \mathrm{h})$. A plastic mesh was included in the setup installation, between the rain simulator and the chamber that contains the paver profile, according to Naves et al. [12] to break rainfall drops reducing its size and improving its spatial distribution. 


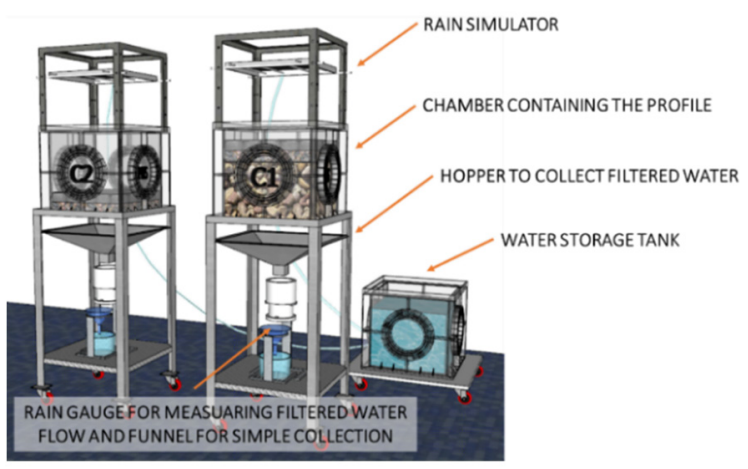

(a)

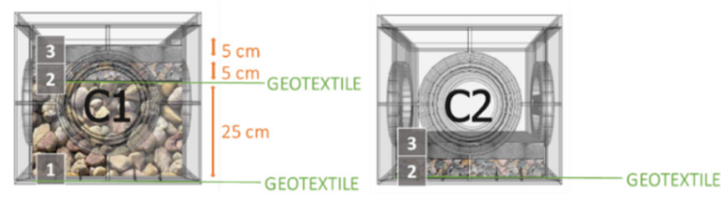

1 - 40 MM WASHED LIMESTONE AGGREGATE

2 - 2 - MM WASHED LIMESTONE GRAVEL

3 PRECAST POROUS CONCRETE

(b)

Figure 1: (a) Scheme of experimental setup; and (b) Cross-section configuration C1 (left) and configuration $\mathrm{C} 2$ (right).

Table 1: Physical-chemical characteristics of the dust and dirt used in the tests. Results are expressed on a dry weight (dw) basis.

\begin{tabular}{|c|c|c|}
\hline \multicolumn{2}{|l|}{ Physico-chemical variable } & Average value \\
\hline \multicolumn{2}{|l|}{ Moisture $(\% \mathrm{dw})$} & 2.02 \\
\hline \multicolumn{2}{|l|}{ Organic matter $(\% \mathrm{dw})$} & 8.23 \\
\hline \multicolumn{2}{|l|}{ Organic carbon $(\% \mathrm{dw})$} & 1.83 \\
\hline \multicolumn{2}{|l|}{ Total nitrogen $(\mathrm{mg} / \mathrm{kg} \mathrm{dw})$} & 1351.0 \\
\hline \multicolumn{2}{|l|}{ Total Phosphorus (mg/kg dw) } & 302.5 \\
\hline \multicolumn{2}{|l|}{ Electrical conductivity $_{1: 5}(\mu \mathrm{S} / \mathrm{cm})$} & 890 \\
\hline \multicolumn{2}{|l|}{$\mathrm{pH}_{1: 5}$} & 8.0 \\
\hline \multirow{3}{*}{ Particle size distribution (\%dw) } & Gravel $(>2 \mathrm{~mm})$ & 13.2 \\
\hline & Sand $(0.063-2 \mathrm{~mm})$ & 85.0 \\
\hline & Silt and clay $(<0.063 \mathrm{~mm})$ & 1.8 \\
\hline
\end{tabular}

The influence of pollution build-up was studied by dry sprinkling sediments on the pavement surface. The applied deposition rate $\left(5 \mathrm{~g} / \mathrm{m}^{2} / \mathrm{d}\right)$ was selected according to the information provided by the cleaning services (mass collected, surface swept and cleaning frequency) and checked against scientific references [13], [14]. Four different pollutant build-up levels effects have been studied: one month $\left(140 \mathrm{~g} / \mathrm{m}^{2}\right)$, three months $\left(420 \mathrm{~g} / \mathrm{m}^{2}\right)$, 6 months $\left(840 \mathrm{~g} / \mathrm{m}^{2}\right)$ and 1 year $\left(1825 \mathrm{~g} / \mathrm{m}^{2}\right)$. 
Only three infiltrometers were available for testing, one with configuration $\mathrm{C} 1$ and two with configuration C2 (Replica 1 and Replica 2). In general, the methodology followed for the trials was applying progressively the dust (1, 3, 6 and 12 months) and simulating the rainfall in each case. Three weeks have passed between tests, on the same infiltrometer, to ensure the same initial moisture conditions. There was an exception for configuration $\mathrm{C} 2$, in which 1 month and 6 month of pollutant build-up level were performed and after that, the surface was cleaned with a vacuum cleaner and a brush, and the assays of 3 and 12 months of build-up levels were performed to complete the data series.

The infiltrated water was collected and kept in the refrigerator until analysis within twenty-four hours. The water samples were analysed for the following parameters: Total Nitrogen (TN) (Spectroquant ${ }^{\mathbb{R}}$ test: [15] photometry), Total Phosphorus (TP) (Spectroquant $^{\circledR}$ test: digestion [16]), Chemical Oxygen Demand - COD (Spectroquant ${ }^{\circledR}$ test: [17]), Total and Volatile Suspended Solids [18], [19] and turbidity with a TN100 Eutech turbidity-meter. WTW-Multi 340i probes were used to measure: temperature, dissolved oxygen $\left(\mathrm{CellOx}^{\circledR}\right.$ 325), conductivity $\left(\right.$ TetraCon $\left.^{\circledR}\right)$ and $\mathrm{pH}\left(\operatorname{SenTix}^{\circledR} 41\right)$.

\section{RESULTS}

\subsection{Influence of pollution build-up and rainfall intensity on infiltrated water quantity}

The hydrographs of infiltrated water obtained in the different tests performed are shown in Fig. 2. Additionally, drained volumes are represented through the cumulative volume curves. Fig. 2(a) collects the results for 1-month pollutant build-up, (b) for 3 months, (c) for 6 months and (d) for 12 months. For 1 and 6 months of dust and dirt accumulation, the maximum flow rates and the lower lag times were reached for simple configuration (Fig. 2(a) and (c)). Lag time is defined as the time elapsed between the beginning of the rainfall and the beginning of the outflow from permeable pavement, as defined in Rodriguez-Hernandez et al. [20]. For 3- and 12-month build-up, these variables did not show a clear pattern.

For configuration $\mathrm{C} 1$, the larger the quantity of pollutant accumulated on the pavement surface, the lower flow rates and the longer lag time. This happened during the first three build-up simulations (1, 3 and 6 months of dirt and dust accumulated) where the flow rate values were $1.36,1.34$ and $1.33 \mathrm{l} / \mathrm{m}^{2} / \mathrm{min}$, respectively, and the lag times increased from 7 to 9 (Fig. 2(a)-(c)). It seems that dust and dirt accumulated on the pavement surface absorbed part of the rain, thus smoothing the peak flow of filtered water and delaying the hydrographs. For the fourth test (12 months), peak flow increased (until $1.75 \mathrm{l} / \mathrm{m}^{2} / \mathrm{min}$ ) and lag time was 5 minutes; thus giving a peak flow higher than the assay performed under 1-month build-up and a lower lag time (Fig. 2(d)). Too much dust $\left(1825 \mathrm{~g} / \mathrm{m}^{2}\right)$ possibly clogged the pores of the pavement, and rainwater could have found preferential paths, short-circuiting and, thus, reducing its buffering capacity. In this assay, runoff was formed, proving some clogging.

For both replicas performed on simple configuration (C2), it can be also observed, for 1 and 6 months, a higher quantity of build-up produces a reduction of peak flows and an increase of lag time (Fig. 2(a) and (c)). However, 3 and 12-months tests (Fig. 2(b) and (d)) produced lower peak flows $\left(1.2 \mathrm{l} / \mathrm{m}^{2} / \mathrm{min}\right.$ and $0.7 \mathrm{l} / \mathrm{m}^{2} / \mathrm{min}$, respectively) and significantly higher lag times (6 and 7 minutes, respectively).

As it has been stated in previous section, infiltrometers with configurations $\mathrm{C} 2$ were tested with one and six months of dust and dirt build-up and then were cleaned with a domestic vacuum cleaner and a brush. After that, three- and 12-months tests were performed. When the cleaning works finished, it was observed that some dirty remained between the joints of the paving blocks. This situation might have caused a delay in rain infiltration, leading to the 

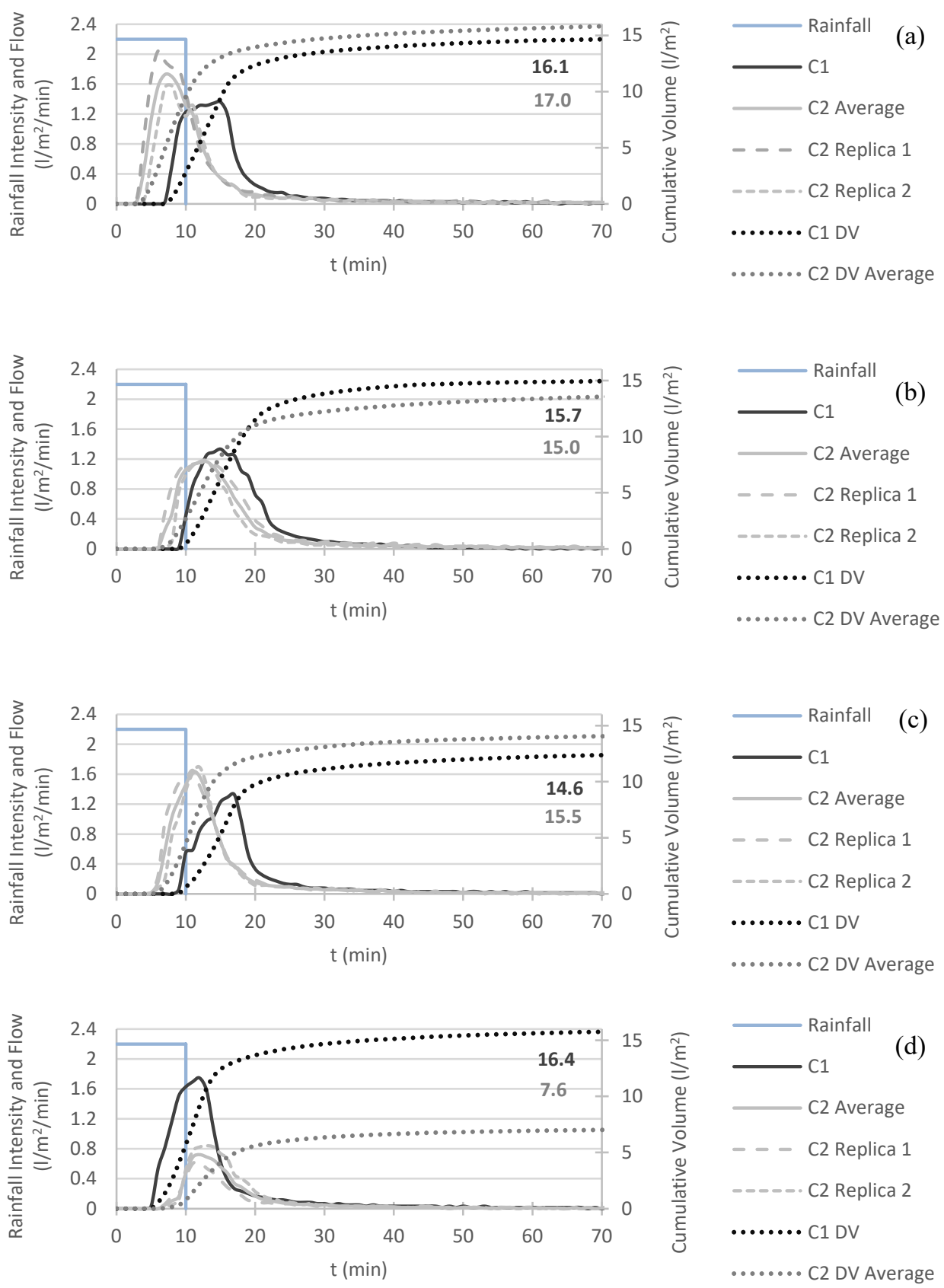

Figure 2: Hydrographs of infiltrated water under different pollution build-up levels for the tested configurations $\mathrm{C} 1$ and $\mathrm{C} 2$. (a) 1 month; (b) 3 months; (c) 6 months; and (d) 12 months. Cumulative volume curves (C1 DV and C2 DV average) are displayed on the secondary axis and numerical data indicate the total drained volume (average value for configuration $\mathrm{C} 2$ ). 

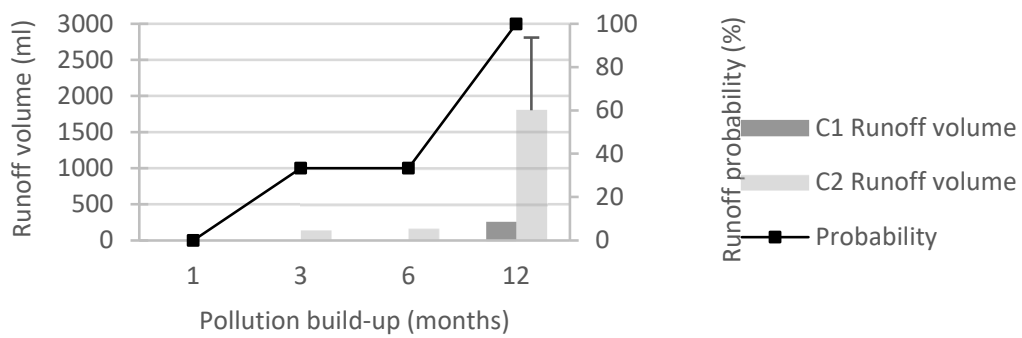

Figure 3: Runoff volume in millilitres for 1, 3, 6 and 12 months of pollutant build-up and both tested configuration $(\mathrm{C} 1$ and $\mathrm{C} 2)$. The probability of runoff occurrence, according to the number of tests carried out, are displayed on the secondary axis.

runoff production (140.5 $\mathrm{ml}$ for three months of build-up and $2516 \mathrm{ml}$ for one year). Most researchers in the field claim pressure/power washing with water and vacuum sweeping (or a combination of these) are the most recommended methods to rehabilitate clogged permeable concrete [21], [22].

In terms of total drained or retained volume, permeable pavements with both configurations were always able to retain a significant part of the total rainfall volume applied, at least $22 \%$ (one-month test - C2 ). In short, retention varies between $24 \%-34 \%$ for complete configuration and between $22 \%-33 \%$ in the simple one $(\mathrm{C} 2)$.

About runoff generation, configuration $\mathrm{C} 2$ produced a runoff volume that increased as the pollution build-up level did (Fig. 3). In contrast, configuration $\mathrm{C} 1$ only produced runoff for 1 year of build-up level $(263 \mathrm{ml})$. Right vertical axis in Fig. 3 shows the probability of runoff occurrence observed in the performed tests. For one month of dust and dirt accumulation, runoff does not occur. Whereas, for three and six months only one of the replicas performed in the simple configuration (C2) produced it. Finally, one-year pollutant build-up produced runoff volume in all the tests. In Drake and Bradford [23] recommended frequency of maintenance ranges from at least once per year and [24], [25] to two to four times per year, depending on the site and weather conditions [26]. Taking into account both configuration, the results show that it is necessary to clean the PPS with a frequency no lower than once a month to maintain an adequate permeability rate and its capability to prevent surface runoff. It could be a good idea, a basic monthly cleaning with mechanical sweeper, just like in any other area of the city.

\subsection{Influence of pollution build-up and rainfall intensity on the quality of infiltrated water}

This section presents the results of the water quality, for $\mathrm{C} 1$ and $\mathrm{C} 2$ configurations. Fig. 4 shows pollutant concentrations for filtered water through the pavements and the runoff generated if it is the case.

Regarding the quality of filtered water, configuration $\mathrm{C} 1$ reached lower concentrations of COD, TN and TP than configuration C2 (Fig. 4(a), (c) and (d) respectively). COD increased progressively with pollutant build-up, reaching concentrations between $77 \mathrm{mg} / 1$ (Configuration C1) and $174 \mathrm{mg} / 1$ (Configuration C2) for one year of dust accumulation (value above $125 \mathrm{mg} / \mathrm{l}$; discharge limit of urban wastewater treatment plants in Spain). This rise is more pronounced for configuration C2 (Fig. 4(a)). 


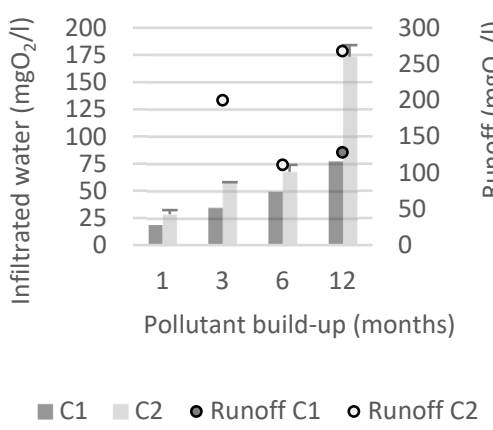

(a) COD

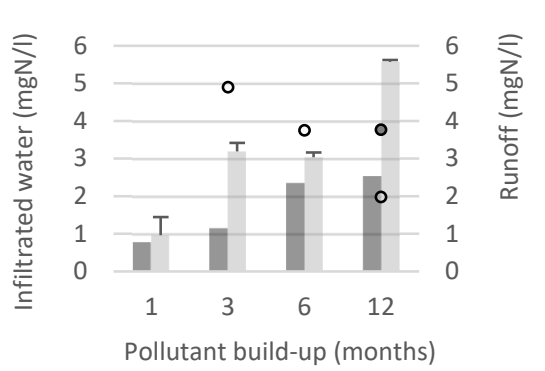

$\square$ C1 C2 oRunoff C1 oRunoff C2

(c) $\mathrm{TN}$

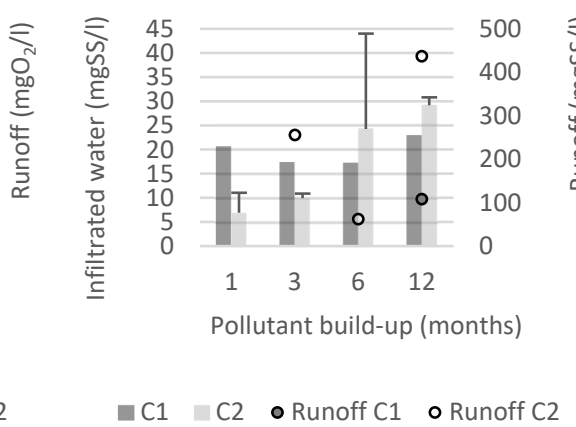

(b) TSS

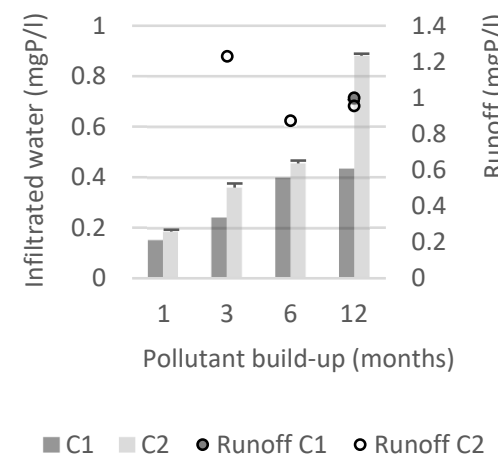

(d) TP

Figure 4: (a) Chemical oxygen demand (COD); (b) Total Suspended Solids (TSS); (c) Total Nitrogen (TN); and (d) Total Phosphorus (TP) concentrations in the different assays performed (1, 3, 6 and 12 months of pollutant build-up in configuration $\mathrm{C} 1$ and $\mathrm{C} 2$ ). Vertical left axis refers to infiltrated water concentrations and vertical right axis to runoff concentrations. The standard deviation is only shown for infiltrated water.

Total Nitrogen and Total Phosphorus concentrations in complete configuration tests have a tendency to increase more in the first tests (the difference between 1 and 3 months of build-up levels is higher) and to steady with dust accumulation (results for 6 and 12 months are quite similar). By contrast, concentrations of these pollutants in simple configuration increase progressively with build-up (Fig. 4(c) and (d)).

The behaviour of TSS concentrations (Fig. 4(b)) is different for both configurations. C2 TSS concentrations increase gradually with deposition. The larger the quantity of pollutant build-up, the larger the concentration of infiltrated water become. Conversely, there is not an important difference among TSS concentration in the water drained by pavements with complete configuration for the different levels of dirty accumulation. Furthermore, it should be highlighted that the amount of TSS leached through the PPS is low in comparison with the amount deposited on the surface, as it is discussed below.

About runoff, as it is commented in the previous section, configuration $\mathrm{C} 2$ produced for 3, 6 and 12 months of pollutant build-up, and configuration $\mathrm{C} 1$ only generated for 1-year 
build-up level. More pollutant accumulation produces higher runoff volumes. For configuration $\mathrm{C} 2$, three-months runoff volume was more concentrated than six-months one. One-year tests produced the higher runoff volumes (Fig. 3) and, especially for configuration $\mathrm{C} 2$, very high pollutant concentrations $\left(268 \mathrm{mgO}_{2} / 1\right.$ of $\mathrm{COD}, 436.8 \mathrm{mgSS} / 1$ of $\mathrm{TSS}$, $1.98 \mathrm{mgN} / 1$ of TN and $0.955 \mathrm{mgP} / 1$ of TP).

So far, the results obtained have been analysed for the concentration of pollutants, but it is also important to analyse the results in terms of released mass load. Fig. 5 shows the percentage of mass leached within the infiltrated water with respect to the total mass present

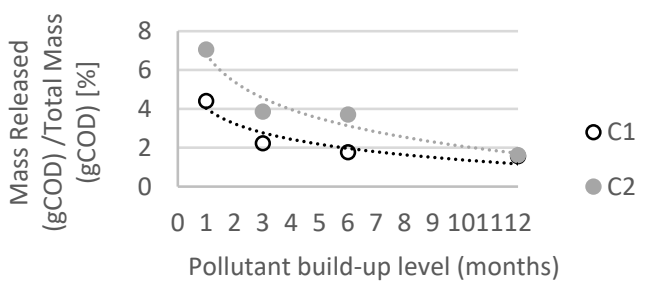

(a) COD
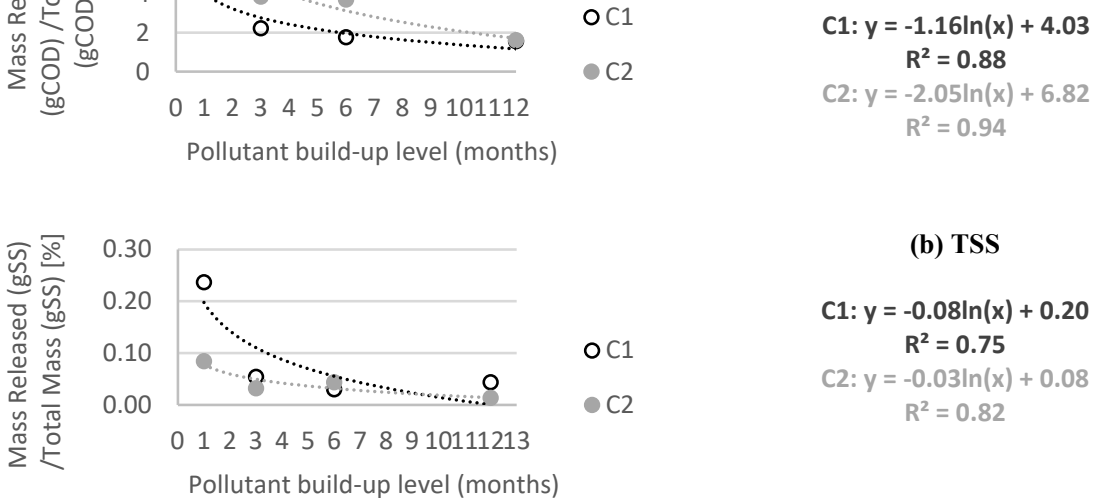

(b) TSS

$C 1: y=-0.08 \ln (x)+0.20$

$R^{2}=0.75$

$C 2: y=-0.03 \ln (x)+0.08$

$\mathrm{R}^{2}=0.82$

Pollutant build-up level (months)

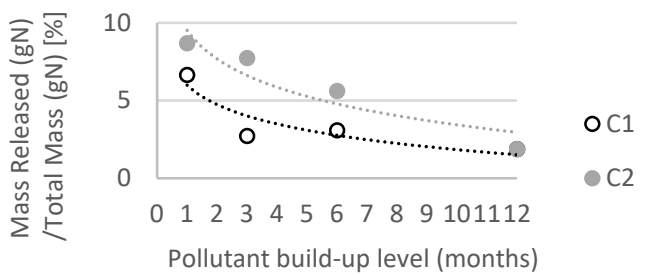

(c) $\mathrm{TN}$

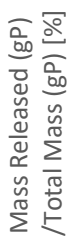

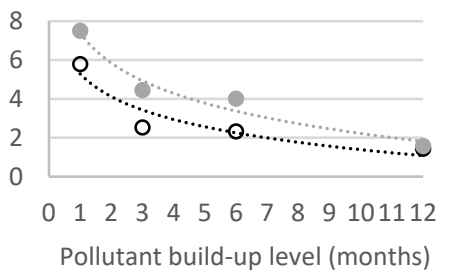

(d) TP

$$
\begin{aligned}
C 1: y= & -1.70 \ln (x)+5.29 \\
& R^{2}=0.89 \\
C 2: y= & -2.25 \ln (x)+7.40 \\
& R^{2}=0.96
\end{aligned}
$$

Figure 5: Evolution of mass of pollutant released with respect to the total mass present in the dust and dirt deposited on the pavement surface (\%) with pollutant build-up level. Dots represent the data (average data for configuration C2) and dotted curves a logarithmic adjustment. On the right are the equations of the adjustment for each configuration ( $\mathrm{C} 1$ and $\mathrm{C} 2$ ) and the coefficient of determination (R2). 
in the dust and dirt accumulated on the pavement surface. It is important to carry out the analysis in terms of mass to quantify the pollutant retention capacity of the different PPS configurations. This analysis reaffirms the higher retention capacity of configuration $\mathrm{C} 1$ (especially for lower values of pollution build-up) considering the effect of volume and concentration together.

The percentage of TSS leached is the lower one, compared with the rest of the variables studied, and the differences between build-up levels are also very low. Both configurations have the greatest retention capacity for the TSS, for all the build-up levels tested. The quantity of solids released is so small for both configurations, thus the difference obtained can be considered negligible.

For all the variables, this percentage of mass leached within the filtered water, can be adjusted to a logarithmic model. That means the mass of pollutant leached trends to reach a constant value with a certain mass of dust and dirt deposited on the pavement surface. This information is interesting and highlight the potential of permeable pavements despite its lack of maintenance. However, as it was stayed above, it is highly recommendable to perform an adequate cleaning programme, to prevent the production of runoff and its potential discharge to aquatic environment.

\section{CONCLUSIONS}

Results have shown that PPS have an important improvement potential compared with conventional pavements. These systems have the capacity to reduce the peak flow and the volume of drained water, temporarily dampening the rain hydrograph. Moreover, they can reduce or even completely avoid the production of runoff in the extreme rainfall events tested and can decrease the pollutant concentrations respect to the surface runoff. However, PPS need to be maintained correctly to perform these advantages and this maintenance must be more frequent for simple configurations.

During extreme events, complete configuration has presented higher buffering capacity of the rainfall events than simple configuration. Peak flows, drained volumes and pollutant concentrations of infiltrated water were higher for configuration $\mathrm{C} 2$, impacting more on receiving environment. Besides, the runoff occurrence probability is higher for simple configuration. Only when its surface has not been cleaned in a year, complete configuration produces runoff, which volume will be probably less than $1.21 / \mathrm{m}^{2}$. Elseways, simple configuration produces runoff for pollution build-up levels higher than one month.

Overall, both configurations could be used in areas where heavy rainfalls occur. Nevertheless, the benefits of complete configuration could make it useful than simple configuration, although its higher structural strength is not required. A cost-benefit analysis should be carried out before making the final decision. For both configurations, it would be advisable to clean the surface of the PPS once a month to avoid surface runoff production and less leachability of pollutants.

\section{ACKNOWLEDGEMENTS}

This research has been developed within the SUPRIS-SUPel project framework (Ref. BIA2015-6540-C2-2-R MINECO/FEDER, EU). This project had been financed by the Ministry of Economy and Competitiveness of Spain through the General State Budget and the European Regional Development Fund (ERDF). Currently, the second phase of the project, ENGODRAIN - RTI2018-094217-B-C31, financed by the State Agency for Research from Spain through the General State Budget and the European Regional Development Fund (ERDF), is continuing. The authors would also like to thank the companies Quadro Concrete Prefabs S.L., TenCate Geosynthetics Iberia S.L., Atlantis SUDS 
S.L. and SECOPSA for supplying materials for the tests. Finally, the hiring of Miriam Inmaculada Fernández Gonzalvo has been possible to the program of subsides for hiring of pre-doctoral research personnel (ACIF/2018/111) of the Generalitat Valenciana.

\section{REFERENCES}

[1] Woods Ballard, B. et al., The SuDS Manual, CIRIA: London, 2015. ISBN: 978-086017-760-9.

[2] Tedoldi, D., Chebbo, G., Pierlot, D., Kovacks, Y. \& Gromaire, M.C., Impact of runoff infiltration on contaminant accumulation and transport in the soil/filter media of sustainable urban drainage systems: a literature review. Science of the Total Environment, 569-570, pp. 904-926, 2016.

[3] Liu, Y., Li, T. \& Peng, H., A new structure of permeable pavement for mitigating urban heat island. Science of the Total Environment, 634, pp. 1119-1125, 2018. https://doi.org/10.1016/j.scitotenv.2018.04.041.

[4] Brown, R.A. \& Borst, M., Nutrient infiltrate concentrations from three permeable pavement types. Journal of Environmental Management, 164, pp. 74-85, 2015. https://doi.org/10.1016/j.jenvman.2015.08.038.

[5] Drake, J., Bradford, A. \& Van Seters, T., Stormwater quality of spring-summer-fall effluent from three partial-infiltration permeable pavement systems and conventional asphalt pavement. Journal of Environmental Management, 139, pp. 69-79, 2014. https://doi.org/10.1016/j.jenvman.2013.11.056.

[6] Kamali, M., Delkash, M., Tajrishy, M., Evaluation of permeable pavement responses to urban surface runoff. Journal of Environmental Management . 187, pp. 43-53, 2017. https://doi.org/10.1016/j.jenvman.2016.11.027.

[7] IPCC, Summary for policymakers. Global Warming of $1.5^{\circ} \mathrm{C}$. An IPCC Special Report on the Impacts of Global Warming of $1.5^{\circ} \mathrm{C}$ above Pre-Industrial Levels and Related Global Greenhouse Gas Emission Pathways, in the Context of Strengthening the Global Response to the Threat of Climate Change, Sustainable Development, and Efforts to Eradicate Poverty, eds V. Masson-Delmotte, et al., World Meteorological Organization: Geneva, 2018.

[8] Jenkins, K., Surminski, S., Hall, J. \& Crick, F., Assessing surface water flood risk and management strategies under future climate change: Insights from an Agent-Based Model. Science of the Total Environment, 595, pp. 159-168, 2017. http://dx.doi.org/10.1016/j.scitotenv.2017.03.242.

[9] Baron, N. \& Petersen, L.K., Understanding controversies in urban climate change adaption. A case study of the role of homeowners in the process of climate change adaptation in Copenhagen. Nordic Journal of Science and Technology Studies, 3(2), pp. 4-13, 2015. https://doi.org/10.5324/njsts.v3i2.2159.

[10] Hernández-Crespo, C., Fernández-Gonzalvo, M., Martín, M. \& Andrés-Doménech, I., Influence of rainfall intensity and pollution build-up levels on water quality and quantity response of permeable pavements. Journal Science of Total Environment, 684, pp. 303-313, 2019. https://doi.org/10.1016/j.scitotenv.2019.05.271.

[11] Rodriguez-Hernández, J., Andrés-Valeri, V.C., Ascorbe-Salcedo, A. \& Castro-Fresno, D., Laboratory study on the stormwater retention and runoff attenuation capacity of four permeable pavements. Journal of Environmental Engineering, 142(2), pp. 04015068, 2016.

[12] Naves, J., Puertas, J., Anta, J., Suárez, J. \& Regueiro-Picallo M., Montaje y calibración de un simulador de lluvia para estudios de drenaje urbano. $V$ Jornadas de Ingeniería del Agua, 24-26 de Octubre, A Coruña, 2017. 
[13] Wijerisi, B., Egodawatta, P., McGree, J. \& Goonetilleke, A., Process variability of pollutant build-up on urban road surfaces. Science of the Total Environment, 518-519, pp. 434-440, 2015. https://doi.org/10.1016/j.scitotenv.2015.03.014.

[14] Zhao, H. et al., Is the wash-off process of road-deposited sediment source limited or transport limited? Science of the Total Environment, 563-564, pp. 62-70, 2016. https://doi.org/10.1016/j.scitotenv.2016.04.123.

[15] ISO 11905-1:1997, Water Quality Determination of nitrogen. Part 1: method using oxidative digestion with peroxodisulfate.

[16] ISO 6878-1:1986, Water Quality. Determination of phosphorus. Part 1: ammonium molybdate spectrometric method.

[17] ISO 15705, 2002, Water Quality. Determination of the Chemical Oxygen Demand Index (ST-COD). Small-scale Sealed-tube Method.

[18] UNE 77034:2002, Water Quality. Determination of volatile and fixed suspension solid.

[19] UNE-EN 872:2006, Water Quality. Determination of suspended solids. Method by filtration through glass fibre filters.

[20] Rodriguez-Hernandez, J., Andrés-Valeri, V.C., Ascorbe-Saceldo, A. \& Castro-Fresno, D., Laboratory study on the stormwater retention and runoff attenuation capacity of four permeable pavements. Journal of Environmental Engineering, 142(2), pp. 04015068, 2015.

[21] Environmental Protection Agency (EPA). National Menu for Best Management Practices, Post-construction Stormwater Management. Environmental Protection Agency (EPA), 2004.

[22] Golroo, A. \& Tighe, S.L., Pervious concrete pavement performance modelling: an empirical approach in cold climates. Canadian Journal of Civil Engineering, 39(10), pp. 1100-1112, 2012.

[23] Drake, J.A.P. \& Bradford, A., Assessing the potential for restoration of surface permeability for permeable pavements through maintenance. Water Science and Technology, 68(9), pp. 1950-1958, 2013.

[24] Gunderson, J., Pervious Pavements: New Findings about Their Functionality and Performance in Cold Climates. Stormwater Magazine, Sep. 2008.

[25] Henderson, V. \& Tighe, S., Evaluation of pervious concrete pavement performance in cold weather climates. International Journal of Pavement Engineering, 13(3), pp. 197-208, 2012.

[26] Kia, A., Wong, Hong S. \& Cheeseman, C.R., Clogging in permeable concrete: A review. Journal of Environmental Management, 193, pp. 221-233, 2017. 